\title{
FULFILMENT OF CRITERIA OF ELECTRICITY SUPPLY RELIABILITY IN THE BALTIC REGION
}

\author{
K. Brinkis, V. Kreslinsh, A. Mutule, \\ I. Oleinikova, Z. Krishans, O. Kochukov \\ Laboratory for Power System Mathematical Modelling, \\ Institute of Physical Energetics, \\ 21 Aizkraukles Str., Riga, LV-1006, LATVIA
}

\begin{abstract}
The paper analyses the reliability of power supply for a $330 / 750 \mathrm{kV}$ electrical ring. Consideration is also given to the influence of emergency automatics on the maximum permissible power flows in different electrical connection points of the ring as well as to the application of reliability criterion $(N-1)$ in the case of using the emergency automatics to limit post-accident power flows in these points. The authors discuss the role of operative and technological management in securing the power supply reliability. They also analyze situations with disconnection of major generation units and its influence on the blackout development.
\end{abstract}

Key words: power systems, large-scale circuits, reliability estimation, reliability improvement, emergency/protection automatics

\section{INTRODUCTION}

Starting in the 1960-ies, the $330 \mathrm{kV}$ transmission network of Baltic States was forming as part of the global electricity generation and transmission network of the Soviet Union [1]. Already in the 1950-ies, the global character of power industry development in this sphere was evident. Nowadays, the small and isolated Latvian power system (PS) is unable to solve the problems of electricity supply and competitive electricity production. It is known that in every time span the active power generation should correspond to the consumption, because only in this case one of the electricity quality criteria - namely, $50 \mathrm{~Hz}$ frequency - is met. Since during one day in the consumption peak- and off-hours the power can change twice, the problem of ensuring the power balance (consumption $=$ generation) becomes actual, especially in a small PS without large power plants and high generation capacities. The cost of electricity production by a large power plant is much lower; at the same time, failure in one of its units would cause a considerable frequency drop which could not be compensated with any emergency measure for example, with consumers' disconnection from the grid, because in this case up to $50 \%$ of a small power system's consumption might be disconnected.

In work [2], the PS frequency curves ( $\Delta F v s$. total capacity $P$, statism $S$ and power deviation $P$ ) are described by the equation:

$$
\Delta F=\frac{S \cdot F \cdot \Delta P}{P}
$$


where $S$ is the PS statism $(0.005-0.1)$;

$F$ is the normal PS frequency.

In the 1980-ies, the Electrical Ring: Moscow - Leningrad (now St. Petersburg) - Estonia - Latvia - Belarus - Smolensk - Moscow was completed. In the ring, every electrical connection point consisted of three-five $330 \mathrm{kV}$ transmission lines except the Moscow - Leningrad connection, which included one $330 \mathrm{kV}$ and one $750 \mathrm{kV}$ transmission lines.

In 1992, Heads of the Baltic States (Estonia, Latvia and Lithuania) decided to integrate three Baltic power systems, with a united coordinating dispatcher center (DC Baltija) in Riga, aimed at maintaining the parallel synchronous operation of the Estonian, Latvian and Lithuanian PSs in the Electrical Ring, which also included those of Russia: Leningrad, Novgorod, Pskov, Tver, Moscow and Smolensk as well as the Belarus PS with its United Dispatcher Department in Minsk (Fig. 1).

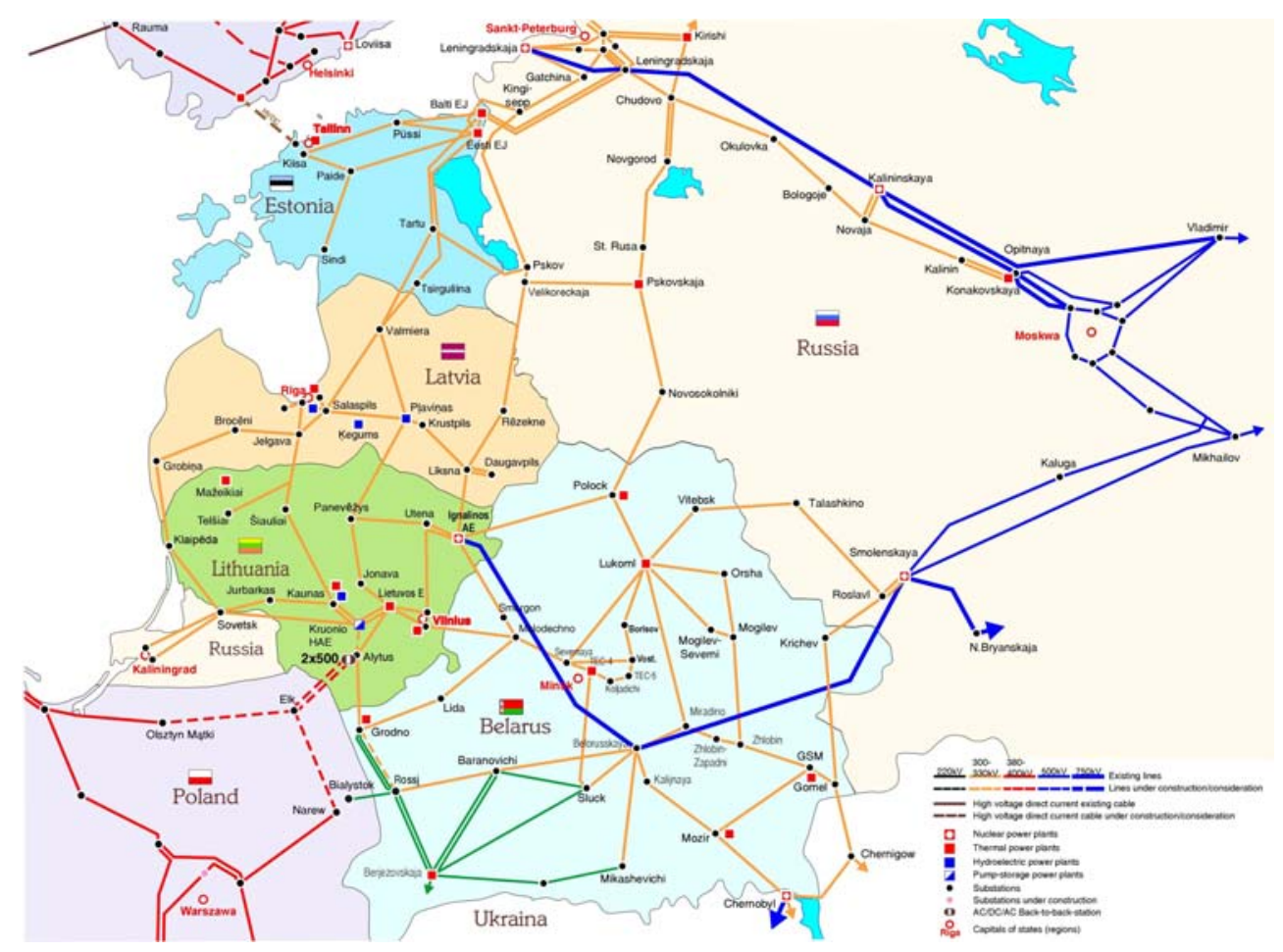

Fig. 1. Baltic Electrical Ring.

The DC Baltija functioned based on the experience of ten dispatcher departments of USSR Northwest PSs (those of Kola, Karelia, Leningrad, Novgorod, Pskov, Estonia, Latvia, Lithuania, Kaliningrad, and Belarus) in operational and technological management, and provided a high level of energy supply reliability. The last blackout in the ring happened in 1984, when $1000 \mathrm{MW}$ of consumption was tripped after automatic separation of the Latvian, Lithuanian, Kaliningrad and Belarus PSs.

To resume the normal operation after $1 \mathrm{~s}$ of a power failure (since phase is damaged within $\sim 1 \mathrm{~s}$ ), in a $300 \mathrm{kV}$ network fast acting relays and single-phase 
automatic reclosing equipment are used, which in $80 \%$ of the single-phase transient faults are able to cope with the task; in addition to the mentioned emergency automatics the local emergency equipment operates, which enables increasing the maximum permissible power flow through $300 \mathrm{kV}$ transmission lines (TLs) of the ring. To achieve that such automatics be capable of operating it is necessary to have emergency power reserve in the region. This reserve is provided by automatic start-up (or shutdown) of the hydro generator or shutdown of the hydro generator operating in the pump regime, as well as by disconnection of electricity consumers for a limited time. In the Baltic states, the power plants used for emergency power reserve purposes are: Plavinu HES (900 MW), Rigas HES (400 MW), Keguma HES (240 MW), and Kruonio HAES (900 MW - both generation and pump regimes).

From the above it follows that to maintain reliable supply a coordinating dispatcher center is needed that would respond to the global character of electricity production, transmission and distribution.

\section{ANALYSIS OF ELECTRICAL CONNECTION POINTS OF THE RING}

Each system of the Electrical Ring makes its own electrical connections, with definite maximum power flow, voltage class, number and length of lines, and the repair schemes.

From the stability point of view, the main feature of a closed electrical ring is that stability loss is possible only at two variable electrical connection points (ECPs); in our case it is the combination Leningrad - Estonia and Smolensk Belarus, or the combination Estonia - Latvia and Smolensk - Belarus.

Combinations of the kind depend on the outage place where the power flow is limited by the condition that the summary flow of two corresponding ECPs has reached its maximum according to the static stability criterion. The advantage of an electrical ring is that the static and dynamic stability criteria for two ECPs are always higher than those for any single ECP.

At analyzing possible emergency situations it should be taken into consideration that the mentioned Electrical Ring is non-uniform and involves repair schemes, especially in summer months.

Such analysis should be done taking into account all possible operational states of power plants connected to the ring, as well as the maximum electricity consumption - for example, when one of the units of a nuclear power plant (the Leningrad, Tver, or Smolensk NPP) is stopped due to a failure entailing a 1000-1300 MW decrease in the generation.

Owing to the ring non-uniformity in definite seasons of the year there could be different combinations of weakened ECPs, which requires that there be a new approach to creation of the adaptive, selective and reliable emergency automatics.

It should be mentioned that the ring in some ECPs is limited by the maximum power flow of 1500-2000 MW, while the repair schemes - even by $600 \mathrm{MW}$. Therefore, in the case of repair schemes and short-circuit at one of the remaining transmission lines of a weakened ECP even possible breakage of Electrical Ring was considered - for example, between Smolensk and Belarus, between Estonia and Leningrad, etc. 


\section{APPLICATION OF $(N-1)$ RELIABILITY CRITERION IN THE BALTIC $330 \mathrm{KV}$ ELECTRICAL NETWORK}

The question as to application of the $(N-1)$ criterion in the Baltic $330 \mathrm{kV}$ network has several answers. If each ECP of a $330 \mathrm{kV}$ transmission network has at least five parallel transmission or transit lines, the disconnection of one line would cause re-distribution of $20 \%$ power among the other four lines. Therefore, average $5 \%$ of the additional power will go to each line, which is permissible. If an ECP has two transmission lines, the disconnection of one line would mean $50 \%$ surplus of power on the other line, i.e. 10 times greater. In the former case the reliability criterion $(N-1)$ is met, while in the latter it is not so. Therefore, there is no technically-economic justification for building a second TL if both lines have permissible overload (1.05 of the maximum). One of the solutions is the use of emergency automatics to ensure permissible power re-distribution among the remaining transmission lines as well as the meeting of reliability criterion $(\mathrm{N}-\mathrm{l})$. The ECPs of Baltic States mostly consist of 3-4 transmission or transit lines [3]. Taking into consideration that the power flow distribution in these lines is not even, a solution for ensuring the mentioned criterion is to utilize emergency automatics or considerably reduce the maximum permissible power flow through ECP. However, in some cases this can entail electricity market restrictions.

It is known that ECP overload can be caused by disconnection of a major generation unit not belonging to the Baltic States (Leningrad NPP, Smolensk NPP and, in the nearest future, also Baltic NPP in the Kaliningrad PS). Also, possible separation of the planned electrical connections with Poland and Sweden should be taken into account, as it can cause power flow re-distribution in the $330 \mathrm{kV}$ TLs and limited fulfilment of the $(N-1)$ criterion if emergency automatics is not used.

To summarize, since the emergency automatics is much cheaper, this solution is undoubtedly much more beneficial economically.

\section{AUTOMATED MANAGING SYSTEMS AND DISPATCHER DEPARTMENT CENTERS}

The operation principle of emergency automatic sets in the case of a "broken" electrical ring differs from that for a closed one; therefore, the necessary corrections should be done.

It is also of importance that there be forecasts of possible static stability failures at the ECPs of Electrical Ring, along with analysis of the consequences to be expected.

Therefore, an automated adaptive coordination system should be created which could affect the local emergency automatics and correct the algorithms of its operation.

Following the static stability loss in an ECP of the electrical ring the power flow in a neighbouring PS will also change, which can lead to cascading static stability loss in one of its ECPs. What kind of responsibility sharing can be in this case, how could it be justified and confirmed? Problems of the kind are solvable with establishment of a dispatching center for coordination of power systems' operation. 
Such a center should possess information based on which the consequences, economic included, could be forecasted in the case of static or dynamic stability loss in any ECP of a PS in the electrical ring, and whether or not justified is to allow such consequences; another question to be answered is: what mechanism of loss compensation should be applied with respect to another PS?

It is clear that, due to diversity of the ECP combinations, local emergency automatics are unable to ensure an adaptive and flexible functioning of the whole electrical ring.

Developing the concept of emergency automatics and the operation principles of electrical ring, it is necessary to take into consideration that its power systems, in compliance with their administrative division, belong to different independent sovereign countries: Estonia, Latvia, Lithuania and Belarus, as well as the Russian Federation. Therefore, mutual solutions and coordination are needed to secure their parallel operation. For this purpose central dispatcher departments were established: Central dispatcher department of the Russian United PS (Moscow), Belarus PS United Dispatcher Department (Minsk), Dispatcher Center of Baltic countries (DC Baltija, Riga, which stopped functioning in late 2006), and the United Dispatcher Department of Russian Northwest PS (St. Petersburg) [2]. The main task of these dispatcher departments was the cooperation on a global scale, solving and agreeing problems arising at PS parallel non-stop operation, as well as the prevention of static and dynamic stability loss in the electrical ring. The concern of dispatcher departments is to achieve operability of all emergency automatics sets, which would ensure a higher maximum for the power flows through ECP.

Of course, some exceptions are possible, when priority is given to separation of a definite regional power system from the ring for independent operation. For example, at a frequency drop below $49 \mathrm{~Hz}$ or $48 \mathrm{~Hz}$ it would be advisable to keep an additional NPP reactor with balanced electrical load for prevention of considerable limitation on the consumer power at post-emergency operation in the case of reactor disconnection. It is known that NPP turbo-generators cannot work in the asynchronous regime, as this can cause triggering of the technological protection.

When evaluating the design and development of emergency automatics to be installed in the ring, it is necessary to work out the mechanism for compensation of mutual losses (capital investments) which would be acceptable to all interested parties. For example, if due to operation of the emergency automatics located at the Leningrad $750 \mathrm{kV}$ substation the Estonian thermal power plants in Narva are unloaded instead of Leningrad NPP, this could cause shutdown of the NPP $500 \mathrm{MW}$ turbogenerator and, possibly, of the reactor. In this case losses incurred to the Estonian power system after emergency automatics operation are compensated in favour of the Leningrad NPP, etc. Stoppage of each reactor causes its idle standing for at least three days, which means that in this time no cheap electrical energy will be produced. Therefore, the mentioned above compensation mechanism is of primary importance, as well as its coordinated application in the PSs of the electrical ring. However, such an approach is difficult to implement on the international level (e.g. in the case of Estonia and St. Petersburg involved). 


\section{GLOBAL APPROACH TO SECURITY OF ELECTRICITY SUPPLY}

The key point in this issue is that the problems of electrical ring cannot be solved locally in separate power systems, because in these cases solutions are neither effective nor economically justified and do not ensure reliable power supply.

At the same time, a global solution implies essentially different principles of local emergency automatics selection, which should be based on the operation of automatic under-frequency load shedding (AUFLS) for disconnection of electricity consumers, triggering parameters of this automatics, range of effect, etc.

To determine in every case the optimal technical solution for electrical ring (e.g. in the case of frequency drop) first of all the CDC has to reconcile mutual disagreements between partners on the following points:

- possible emergency situations in the electrical ring when one or more power systems are automatically disconnected from it, which would cause a frequency decline;

- accommodation of additional load at automatic separation of a significant amount of consumption by PSs that are still in operation;

- possible emergency events that should be considered as local and the mechanism of their appearance (e.g. a PS or an electrical network is automatically disconnected from the ring).

The dispatcher center of Baltic countries up to 2006 was participating in the maintenance of frequency by regulating the external balance and performing frequency correction [4]. Although the automatic system had been completed and ready to use by 2008 (when its commissioning was planned), it was not installed due to liquidation of DC Baltija department. Currently, each Baltic country regulates its external balance manually.

Of course, in a united power system it is technically impossible to prevent a frequency fall due disconnection of a major generation unit. For example, in 2008 (June 25) at the Belarus Lukomla power plant after the disconnection of eight turbo-generators $(8 \times 300 \mathrm{MW})$ the frequency dropped by $0.11 \mathrm{~Hz}$. Another example is the Sayano-Shushenskaya HES event in 2009 (August 25), in which $3600 \mathrm{MW}$ of power was lost, while the frequency in the united power network dropped by $0.12 \mathrm{~Hz}$. The probability of such large-scale emergency events (followed by considerable frequency variations that can lead to triggering the frequency load shedding automatics) is many times lower as compared with local failures or power network disconnections from the electrical ring.

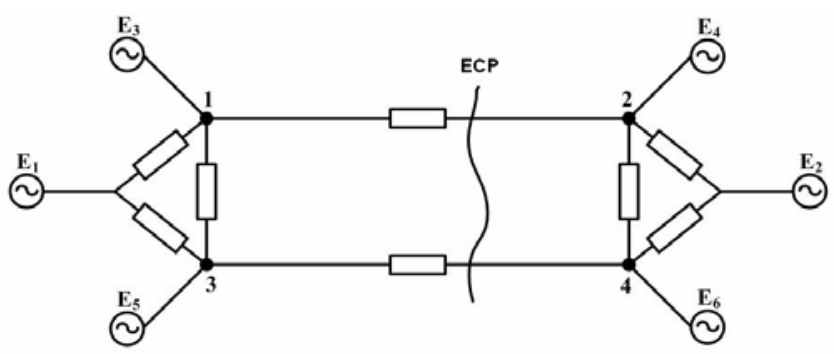

Fig. 2. Simplified circuit of the electrical ring. 
Figure 2 shows schematically a circuit of the electrical ring where $E$ is one of the possible "weak" ECPs. In turn, from Fig. 3 and the formula below it is possible to define the maximum permissible active power flow through a "weak" ECP:

$$
P_{m}=\frac{E_{1 \Sigma} \cdot E_{2 \Sigma}}{Z_{\Sigma}} \cdot \sin \delta,
$$

where $E_{1 \Sigma}$ is the equivalent voltage on one side of ECP;

$E_{2 \Sigma}$ is the equivalent voltage on the other side of ECP;

$Z_{\Sigma}$ is the summary impedance between equivalent voltages;

$\delta \quad$ is the angle between equivalent voltages.

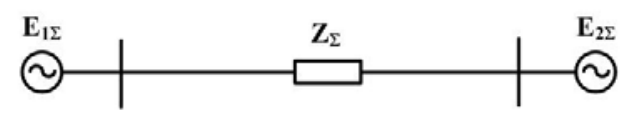

Fig. 3. Simplified circuit of a "weak" ECP.

In the cases described above it is necessary to receive incessant information about two "weak" ECPs of electrical ring where the total summary active power is limited by the stability criterion. Obviously, this cannot be provided in decentralized way, without considering the global principles and coordination of the dispatcher centers. This should be taken into account when planning the daily operational state and agreeing it with partners, as well as performing repair works in the agreed time period.

With some accuracy it is possible to forecast all possible emergency situations which are stemmed from disconnection of a faulty element (transmission line, bus, transformer, generator, etc.) from the power network. A more complicated situation is when there are device or facility faults, since in these cases we are dealing with a cascading shutdown of devices (facilities) entailing a time delay or disconnection of the "wrong" element from the power network.

\section{BLACKOUT IN THE UNITED POWER SYSTEM OF BELARUS}

In the morning of 25 June, 2008 during the peak hours at the Belarus Lukomla power plant after a short-circuit one $300 \mathrm{MW}$ block was disconnected, and eight minutes later - the remaining seven $300 \mathrm{MW}$ blocks with the total power of $2100 \mathrm{MW}$. Before this event, the ECP Smolensk - Belarus operated in the repair scheme (one $330 \mathrm{kV}$ transmission line was disconnected) and the maximum power flow limitation was $800 \mathrm{MW}$. In fact, through the ECP at that moment the maximum power was flowing.

After a one-phase fault at the bus of the $8^{\text {th }}$ block (transformer-generator) it was disconnected. Short-circuit current $(>20 \mathrm{kA})$ was distributed among the grounding circuits of power plant and reached the metal tubes with compressed air connected to $330 \mathrm{kV}$ circuit-breakers. A spark between a metal tube and the ground due to high value of short-circuit current melted a hole in the tube, through which the air was let out. Eight minutes later the chamber of the circuit-breaker had no compressed air left, and the contacts arbitrarily closed - i.e. an unexpected circuitbreaker switching-off took place, which led to a partial phase operational state of 
the disconnected $8^{\text {th }}$ block. The current through the arbitrarily connected circuitbreaker was $>2 \mathrm{kA}$, because the turbo-generator lost excitation after its emergency shutdown, with its rotation speed dropped under nominal thus reducing the generator's resistance. In the asymmetrical operational state the reverse-sequence current protective automatics of the turbo-generator operated without time delay, but mistakenly the circuit-breaker fault automatics was not launched (the circuitbreaker cannot be controlled without compressed air, so protective automatics is of no use in such cases). If a neighbouring backup system had operated, the nearby circuit-breakers would have been disconnected but all seven blocks and the electrical network as a whole remained operable. The asymmetry of currents caused action of the ground-fault protective automatics of remaining seven blocks' transformers with the time delay of $6 \mathrm{~s}$, which led to disconnection of all $330 \mathrm{kV}$ circuit-breakers of these blocks. After their disconnection (with the $8^{\text {th }}$ block phase "C" remaining connected) the partial phase operational state continued with respect to the rest of $330 \mathrm{kV}$ electrical network, causing cascading disconnections of all seven outgoing transmission lines at the opposite side by triggering the backup zones of its ground-fault protective automatics. Loss of $2400 \mathrm{MW}$ generation capacity and disconnection of TLs in Belarus caused a considerable weakening of the electric ring Moscow - St. Petersburg - Estonia - Latvia - Lithuania - Belarus Smolensk - Moscow in the Belarus territory. At the remaining $330 \mathrm{kV}$ and $750 \mathrm{kV}$ transit TLs the power flow rose from the maximum of $800 \mathrm{MW}$ to $2050 \mathrm{MW}$ and $1400 \mathrm{MW}$, respectively, causing considerable overload (1.4 of the permissible) of the $750 / 330 \mathrm{kV} 1000$ MVA transformer at the Belarus substation.

At the $750 / 330 \mathrm{kV}$ transformer the overload current emergency automatics was triggered (the setting was $15 \%$ over $\mathrm{P}_{\text {nom }}$ ) with a 5 min. delay, which impacted on the hydro-generator cascade of Daugava power plants (Plavinu, Keguma and Rigas) with total power of $750 \mathrm{MW}$ (actually, within this time up to $1000 \mathrm{MW}$ total could be reached). On the overload emergency automatics triggering, the Belarus electricity consumers were the first to be disconnected (the $1^{\text {st }}$ stage disconnected $200 \mathrm{MW}$, and each next $-200 \mathrm{MW}$ ). Changing operative and technological management structure in the electrical ring in PSs of Baltic countries (recall that the DC Baltija was liquidated at the end of 2006), the United Dispatching Department (UDD) of Belarus by themselves made the decision to abandon the automatic disconnection of electricity consumers in the case of overload emergency automatics triggering. To decrease a dangerous overload, UDD prepared an operative order to disconnect the electricity consumers up to $800 \mathrm{MW}$, after which (45-50 min. later) the overload at the AT $750 / 330 \mathrm{kV}$ transformer was eliminated. After several hours the $330 \mathrm{kV}$ TEL between Belarus and the Ukraine resumed operation. This accident was close to the total blackout, which could affect also the Latvian PS. For example, if the power flow from St. Petersburg to Estonia under normal operation was close to the nominal value, the dynamic stability loss would be summary for the connections: St. Petersburg - Estonia and Smolensk - Belarus. After triggering the emergency automatics by angle, in the basic zones an isolated region (Estonia, Latvia, Lithuania, Belarus and Kaliningrad) would appear with a power deficit $\sim 3500 \mathrm{MW}$, causing frequency drop to 45-46 Hz. If on the transmission line of Smolensk - Belarus ECP a fault of the fast separation emergency automatics happened with a pre-defined resistance change in 
time (at the DC Baltija such a fault had already been calculated before 2006), the asynchronous operational state of the mentioned ECP could have been liquidated after three asynchronous cycles. It is known that at angle $\delta$ between the equivalent EMFs from $180^{\circ}$ to $360^{\circ}$ the power flow direction is changing, and a power plant of the isolated region starts to transmit power to the united PS with surplus. Such being the case (for example, the Italian PS event of 2003), the deficit of active power in the isolated region grows, power plants become overloaded, and the network voltage is rapidly decreasing, which leads to blackout.

\section{THE ROLE OF EMERGENCY AUTOMATICS}

Since there is limitation of the permissible active power flow through ECP, correct evaluation of all possible emergency situations should be done. For this as well as for elimination of such a situation it is necessary: to install emergency automatics sets at the corresponding nodes of a power network, and to plan the daily operational states and repair works meant for prevention of the critical power flow through ECPs in probable emergency situations. However, this not always is possible, because the primary schemes of many substations do not ensure fulfilment of the $\mathrm{N}-\mathrm{l}$ criterion (in the case of one element's fault other elements could also be disconnected).

It should be noted that the settings of emergency automatics related to $\mathrm{PK}_{\mathrm{i}}$ (the summary power flow through two "weak" ECPs) are calculated at CDCs. The $\mathrm{PK}_{\mathrm{i}}$ is changed automatically in the case of repair and other works, e.g. after disconnection of a TL in one of the ECPs (making it "weaker") where $\mathrm{PK}_{\mathrm{i}}$ is controlled from the mentioned centers (manually or automatically). If the power flow before a failure is higher than the set value for a definite time (based on the calculations taking into account topographical changes (,weakening”) in the ECP electrical circuits), the emergency automatics of the corresponding node in the ring receives a control signal from the CDC to change its operational algorithm. In an emergency situation, for the overloaded ECP (e.g. due to disconnection of a transmission line) the correction of generating capacities or disconnection of consumers are performed to balance the post-accident operation state.

To define and control the "weak" ECPs, at the CDC the latest information and measurement results should be available. All the data are to be received from all substations of the electrical ring, because only in this case it is possible to adjust correctly $\mathrm{PK}_{\mathrm{i}}$, and, therefore generation capacity at power plants as well as the emergency disconnection volume in the real time. The optimal solution for adjusting the generation capacity is to find the correct number of start-ups or shutdowns for the hydro-generator before the emergency operational state arises.

Not always it is possible for a CDC to control outages using emergency automatics sets via adjusting the generation capacity at a power plant. For example, in the described above event in Belarus PS up to $800 \mathrm{MW}$ of consumption were tripped (in four $200 \mathrm{MW}$ steps) due to the absence of a hydro-power plant.

Obviously, all technical solutions that improve the reliability of power supply in an electrical ring have to be realized with adaptive emergency automatics sets.

Merging the Russian, Ukrainian, Byelorussian and Baltic power systems with the United PS of the European Union we would receive one huge power sys- 
tem with $\sim 800000 \mathrm{MW}$ consumption. Such a global power system would allow reducing considerably the expenses of different specific global services, e.g. those involving frequency regulation with the use of primary power reserve.

It is calculated that at a frequency deviation of $0.02 \mathrm{~Hz}$ it is necessary to change the generation capacity by at least $3200 \mathrm{MW}(S=0.1)$.

Of course, the expenses of such a CDC will be rather high; however, this would be repaid owing to higher electrical energy quality and power supply reliability that would be provided by a global power system at synchronous operation.

Besides, creation of a super-large power system will help to raise production of electrical energy as competitive product: the higher generation power, the lower are the electricity production costs and fuel consumption (therefore, the less environment pollution). However, to erect a high-power ( $>500 \mathrm{MW}$ ) plant and high-voltage $(>330 \mathrm{kV})$ TLs a mutual cooperation of power systems is needed. In addition, the open market of electricity implies reduction in the costs of its production as well as in the environment pollution.

Of course, the usage of large generation units in PSs requires higher costs of CDC services that are to control the emergency and regulating power reserves; however, these expenses will be fully justified.

\section{LOCAL EMERGENCY AUTOMATICS}

We are coming now to the role played by the local emergency automatics, whose main task is to localize a blackout not allowing it to expand. Its operation principles are based on the determination of angle $\delta$ between two modelled voltages of a power network [3]. In the case of stability loss in one of the ECPs in the ring a fault in another ECP (or in other cases) the local emergency automatics will act due to the angle $\delta$ increment to the value pre-defined for the basic zone (up to $120^{\circ}$ between the equivalent EMFs) if the center of electrical oscillations is located in the zone between the modelled voltage vectors (i.e. when TL tripping in the ECP is ensured). Its operation will cause separation of one or more PSs from the ring thus forming "islands" with increased or decreased frequency, and will not allow the blackout to spread to the neighbouring PSs. Such local emergency automatics sets are installed on $330 \mathrm{kV}$ transmission lines in the ECPs: St. Petersburg, Estonia - Latvia, Estonia - Pskov, Latvia - Pskov, Latvia - Lithuania, including the transit $330 \mathrm{kV}$ lines Latvia - Lithuania - Kaliningrad, Lithuania - Belarus, and Belarus - Ukraine. Mutual selectivity of local emergency automatics sets related to angle $\delta$ is ensured by fitting the modeled voltages, because there is only one electrical oscillation center located in the operation zone of only one emergency automatics set (i.e., only one set can respond in accordance with the location of electrical oscillation center).

The mentioned emergency automatics sets are used in $330 \mathrm{kV}$ networks, causing TL tripping from the opposite side if angle $\delta$ exceeds the value predefined for the reserve zone, thus leading to the electrical ring break at $\delta>180^{\circ}$. This operation is performed if there was fault of the emergency automatics in the basic zone or of the circuit-breaker located on the same side with the emergency automatics. Combination of these automatics would prevent blackouts in the Baltic PSs and support development of the open electricity market. 


\section{EMERGENCY AND REGULATION POWER RESERVES}

To regulate the external balance through frequency correction, the regulation power reserves are used, which, as a rule, cannot be combined with the emergency power reserve.

Of course, in some cases the emergency and regulation power reserves can be combined, because the former is used very rarely as compared with the latter. For example, if one of the ECPs of electrical ring employs the maximum power limitation automatics (state automatics), it can use the emergency power reserve to ensure that such automatics would be operable, since the regulation power reserve could be insufficient.

In the Baltic region the opportunities provided by the Kruonio hydroaccumulation power plant are effectively employed; for example, when its hydro aggregates are in the pump regime, the emergency automatics sets of the Baltic and Belarus PSs can cause shutdown of hydro-accumulation pumps at a power plant thus blocking the consumer disconnection in the region. In this case the corresponding disconnection circuits are interrupted, because the Kruonio hydro aggregates are in the pumping regime (one such hydro-aggregate consumes in this regime 220-230 MW from the network).

The coordination emergency automatics of the type is installed at the Plavinu HES, the Ingalina substation, the $750 / 330 \mathrm{kV}$ Belarus substation, etc.

\section{CONCLUSIONS}

1. Power supply reliability can be improved by coordinating the operation of emergency and maximum power flow limitation automatics sets.

2. A united power system should have both emergency and regulation power reserves, which cannot be combined (except some cases).

3. To prevent blackouts it is necessary to use the local emergency automatics that would stop the asynchronous running at the angle $120-140^{\circ}$ between the equivalent EMFs.

4. Reliability criterion $N-1$ can be provided by the appropriate emergency automatics.

\section{REFERENCES}

1. Brinkis, K., Kreslinsh, V., \& Ositis, J. (2011). Energosistēmu starpvalstu dispečervadības piecdesmitgade. Energija un pasaule, 70 (5), 22-33 (in Latvian).

2. Brinkis, K. (2003). Totālo avāriju izcelsmes iemesli energosistēmās. Energija un pasaule, 23 (6), 34-39 (in Latvian).

3. Kreslinsh, V., \& Brinkis, K. (1998). Stability and reliability of power supply for consumers in Baltic countries. Latv. J. Phys. Tec. Sci., (1), 3-18.

4. Brinkis, K. (2007). On the frequency control and power reserves in the energy system of Latvia and Baltic States. Latv. J. Phys. Tec. Sci., (4), 3-10. 
PAR ELEKTROAPGĀDES DROŠUMA KRITĒRIJU IZPILDI

BALTIJAS VALSTU REĢIONĀ

K. Briṇķis, V. Krēsliņš, A. Mutule,

I. Ol̦eiņikova, Z. Krišāns, O. Kočukovs

Kopsavilkums

Šajā rakstā dota $330 \mathrm{kV}$ un $750 \mathrm{kV}$ elektriskā gredzena drošuma problēmu analīze un novērtējums. Pielietoto automātikas iekārtu ietekme uz maksimāli pieļaujamām jaudas plūsmām elektriskā gredzena atsevišķos šķēlumos. Drošuma kritērija $(N-1)$ pielietojums gadījumos, ja tiek izmantotas pretavārijas automātikas, kas ierobežo pēcavārijas jaudas plūsmas elektriskos šksēlumos. Operatīiās un tehnologiiskas vadības loma elektroapgādes drošuma kritēriju paaugstināšanai. Lielu generējošo jaudu avārijas atslēgšanās iespējas un ietekme totālās avārijas izraisiš̌sanai.

24.11.2011. 